\title{
DETECTION OF MYCOBACTERIUM BOVIS DNA IN NASAL SWABS FROM TUBERCULOUS CATTLE BY A MULTIPLEX PCR
}

\author{
Eduardo Eustáquio de Souza Figueiredo ${ }^{1}$; Ricardo Cezar Tavares Carvalho²; Flávia Galindo Silvestre ${ }^{2}$; Walter \\ Lilenbaum $^{3}$; Leila Sousa Fonseca ${ }^{1}$; Joab Trajano Silva ${ }^{1}$; Vânia Margaret Flosi Paschoalin ${ }^{{ }^{*}}$ \\ ${ }^{1}$ Universidade Federal do Rio de Janeiro, Rio de Janeiro, RJ, Brasil, ${ }^{2}$ Universidade de Cuiabá, Cuiabá, MT, Brasil, ${ }^{3}$ Universidade \\ Federal Fluminense, Niterói, RJ, Brasil. \\ Submitted: June 23, 2009; Approved: October 06, 2009.

\begin{abstract}
Detection of tuberculosis in cattle relies on the intradermal tuberculin test (ITT), but a definitive diagnosis requires identification of the pathogen after the animal is slaughtered. DNA in nasal swabs from 50 cows was analyzed by m-PCR, targeting for the RvDI-Rv2031c and IS6110 sequences. M. bovis was identified in two of 34 tuberculous cows (5.9\%). The use of mPCR of nasal swabs as an in vivo diagnostic tool for bovine tuberculosis is suggested.
\end{abstract}

Key words: Mycobacterium bovis, multiplex-PCR, nasal swab, bovine tuberculosis

Bovine tuberculosis (BT) is a major problem in many countries, and poses economic and public-health hazards. In Brazil, despite an official control program based on a test-andslaughter policy, the reported prevalence of this disease in cattle ranges from $0.7 \%$ to $2.8 \%(17,1)$, and economic impact studies suggest a $25 \%$ impairment of production (16).

Bovine tuberculosis infection in cattle is usually diagnosed in the live animal based on delayed hypersensitivity reactions (intradermal tuberculin tests), which may lack both sensitivity and specificity (20). However, a definitive diagnosis is still established by isolation and identification of the etiological agent (Mycobacterium bovis) from lymph nodes or lungs, obtained during necropsy or at slaughter, using a combination of traditional culture and biochemical methods; this is considered as the "gold standard method". These methods are slow, cumbersome, unreliable, and time-consuming (it may take more than 4 weeks to grow the microorganism, and an additional 2 weeks to identify it). Several alternative approaches have been attempted for the rapid and specific diagnosis of tuberculosis (5), but the molecular methods, especially polymerase chain reaction (PCR) assays, are the most promising.

A number of PCR-based protocols have been developed for the detection of mycobacteria belonging to the Mycobacterium tuberculosis complex (MTC), which comprises five species (Mycobacterium tuberculosis, M. bovis, $M$. africanum, M. microti and M. canetti). (21, 24). The most common protocols use primers that amplify segments of the IS6110 genomic insertion characteristic of $\operatorname{MTC}(4,6)$. Specific identification of $M$. bovis strains by PCR focuses on the amplification of a 500-bp DNA fragment located inside a genomic 4,999-bp region at the 3' end of a putative gene called $R v D 1-R v 2031 c$, which is not present in other mycobacterial species (18). Although these DNA tests are more reliable and much more rapid than traditional identification methods, tissue samples are still required, and the tests are still limited to the post-mortem diagnosis of the infection, despite some studies regarding their use on milk samples $(25,8)$. 
In this study, the aim was to standardize a multiplex PCRbased method for the simultaneous detection of mycobacteria belonging to MTC and the specific identification of $M$. bovis, using DNA samples extracted from nasal swabs collected from live cows. A total of 50 adult cows from a dairy herd with a previous history of bovine tuberculosis, including clinical cases, from Macaé city (Rio de Janeiro state, Brazil), were tested by the cervical comparative intradermal tuberculin test (ITT) with PPD (purified protein derivative) according to official standards (3). In parallel, samples of nasal mucus were collected using sterile swabs, and submitted to both microbiological culture and $\mathrm{m}-\mathrm{PCR}$.

All 34 ITT-reactive animals $(68 \%$ of the total cows examined) were slaughtered; the lungs and lymph nodes were removed and processed for bacteriology according to the OIE Terrestrial Manual (15). Briefly, after decontamination by the Petroff method, tissue samples from the lungs and lymph nodes, and nasal swabs were inoculated on Lowenstein-Jensen and Stonebrink agar slopes, and the tubes were incubated at $37^{\circ} \mathrm{C}$ for up to 12 weeks. The presence of $M$. bovis and other mycobacteria belonging to MTC in the nasal mucus was investigated by a single-step multiplex PCR (m-PCR), using two sets of primers previously described (8) that target simultaneously the $R v D 1-R v 2031 c$ (specific for $M$. bovis) and IS6110 (present in all MTC species) genomic sequences, but that to date had not been used together in a single m-PCR assay. DNA was extracted from the nasal swabs by a modification of a QIAamp Blood and Tissue Kit (Qiagen). The bacterial pellet was suspended in $180 \mu \mathrm{l}$ of $20 \mathrm{mg} / \mathrm{mL}$ lysozyme in $20 \mathrm{mM}$ Tris. $\mathrm{HCl}, \mathrm{pH} 8.0 ; 2 \mathrm{mM}$ EDTA; and 1.2\% Triton, and incubated for $30 \mathrm{~min}$ at $37^{\circ} \mathrm{C}$ prior to the proteinase $\mathrm{K}$ treatment, in order to improve the process of bacterial lysis. DNA eluted from the QIAamp Mini spin columns was concentrated by precipitation with absolute ethanol at $-80^{\circ} \mathrm{C}$. $\mathrm{m}$-PCR was performed in a reaction $\operatorname{mix}(50 \mu \mathrm{L})$ containing 5 $\mu \mathrm{l}$ of $10 \times$ PCR buffer (Invitrogen), $200 \mu \mathrm{M}$ dNTP (GE Healthcare), $2.5 \mathrm{U}$ of recombinant $\mathrm{Taq}$ polymerase (Invitrogen), $2.0 \mathrm{mM} \mathrm{MgCl} 2,5 \mu \mathrm{L}$ of DNA, and $0.2 \mu \mathrm{M}$ of each primer (JB21 (5'-TCGTCCGCTGATGCAAGTGC-3') and JB22 (5'-CGTGAACGTAGTCGCCTGC-3'), targeting for the RvD1-Rv2031c sequence; and INS1 (5'CGTGAGGGCATCGAGGTGGC-3') and INS2 (5'GCGTAGGCGTCGGTGAC AAA-3'), targeting for the IS6110 region. Amplification was carried out in a GeneAmp PCR System 9600 (Applied Biosystems), using an initial denaturation step at $94^{\circ} \mathrm{C}$ for $5 \mathrm{~min}$, followed by 30 cycles of denaturation at $94^{\circ} \mathrm{C}$ for $1 \mathrm{~min}$, annealing at $68^{\circ} \mathrm{C}$ for $1 \mathrm{~min}$, and elongation at $72^{\circ} \mathrm{C}$ for $1 \mathrm{~min}$. Cycling was completed by a final elongation step at $72^{\circ} \mathrm{C}$ for $7 \mathrm{~min}$. The reaction products were resolved by electrophoresis on a $1.5 \%$ agarose gel followed by ethidium bromide staining $(10 \mu \mathrm{g} / \mathrm{mL})$ and examination under UV light.

No mycobacterial growth was observed on agar slopes inoculated with nasal swab samples collected either from ITTreactive or ITT-negative cows. However, mycobacterial colonies were observed in cultures from lungs or lymph node samples isolated from 17 of 34 PPD-positive cows (50\% of the total of positive cows). In parallel, nasal swabs were searched for the presence of mycobacteria by m-PCR. DNA was extracted from nasal swabs collected from 34 ITT-reactive and 16 ITT-negative cows, using a modification of a QIAamp Blood and Tissue Kit (Qiagen) that was devised to improve bacterial lysis and concentrate DNA. The nucleic acids isolated from all samples using the above-modified procedure showed high quality in terms of integrity and purity, and were suitable to be used as templates in the m-PCR. The $500 \mathrm{bp}$ fragment specific for $M$. bovis and the $245 \mathrm{bp}$ fragment diagnostic for MTC were simultaneously observed in two of $34(5.9 \%) \mathrm{m}$ PCR reactions performed that used nasal swabs containing DNA from ITT-reactive cows (Figure 1, lanes 1 and 2). Importantly, neither the $500 \mathrm{bp}$ band nor the $245 \mathrm{bp}$ band was found as an $\mathrm{m}$-PCR reaction product when swabs from ITTnegative cows were tested (results not shown).

M. bovis has been recovered from nasal exudates collected from cattle in naturally infected herds by using conventional culture techniques $(4,12,13)$. In these reports, recovery efficiencies varied from 8.7 (4) to $28.5 \%$, when only ITTreactive animals were assessed (13), regardless of the difficulty 
of the procedure. The efficiency is low because the presence of $10-100$ viable organisms in the sample is required for a positive result, a condition attained only in advanced stages of the disease (2).

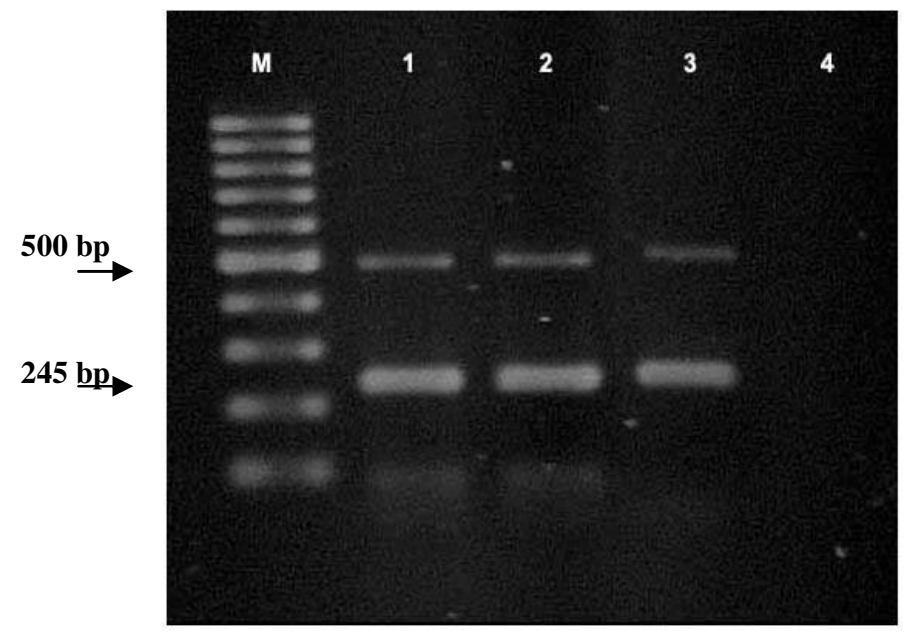

Figure 1. Identification of $M$. bovis in nasal swabs by m-PCR. DNA obtained from nasal swabs of 34 reactive and 16 nonreactive animals was used as templates for simultaneous amplification of the RvD1-Rv2031c and the IS6110 sequences. PCR products were resolved by electrophoresis on $1.5 \%$ agarose gel and stained with ethidium bromide $(10 \mu \mathrm{g} / \mathrm{mL})$. Lane M: 100 bp DNA ladder (Fermentas Life Sciences); lanes 1-2: DNA from ITT and bacteriological-positive animals; lane 3: positive control (DNA from $M$. bovis IP); lane 4: negative control (PCR without DNA template). Arrows indicate the position of the $500 \mathrm{bp}$ (diagnostic for M. bovis) and the $245 \mathrm{bp}$ (diagnostic for MTC members) fragments.

In one study using PCR-based methods, the presence of MTC-group species in nasal exudates of ITT-reactive animals was detected in $26 \%$ of tested samples (22). Some studies have reported detection rates of 50 or $58 \%(13,23)$. These rates seems to be rather low, because some PCR techniques can detect $M$. bovis using as little as $5 \mathrm{fg}$ of DNA, which corresponds to the amount of nucleic acid in a single mycobacterial genome (7). These lower-than-expected results were probably caused by limitations in the current PCR protocols for detection of mycobacteria in nasal exudates, such as intermittent shedding, inefficient DNA extraction, or the presence of PCR inhibitors in the samples (5).

In the present study, none of the nasal-exudate samples from 34 ITT-reactive cows was found to be positive for the growth of $M$. bovis. Furthermore, 2 of 34 nasal-exudate samples $(5.9 \%)$ were positive for $\mathrm{m}-\mathrm{PCR}$, a more sensitive and specific method than culturing $(13,25,26)$. These figures are lower than those previously obtained by using culture or PCRbased methods for the presence of $M$. bovis in nasal exudates $(4,13,13,22,23)$. These low figures may be a consequence of the small number of viable bacteria in swab nasal samples, because the growth of the etiological agent was observed in cultures of lung and lymph-node samples from 17 of the cows, using the same procedure.

It has been well documented that in cattle experimentally infected with $M$. bovis, after every infection there is a lag period during which the microorganism cannot be isolated from nasal mucus $(11,10,14)$. In one study, all the experimentally infected animals shed $M$. bovis in nasal mucus (14); however, failure of some experimental animals to shed mycobacteria has also been reported (10, 11). Importantly, differences in the shedding profiles were observed, where those animals shedding $M$. bovis in nasal exudates were classified as intermittent or otherwise as persistent shedders. It also appears that the overall level of shedding increases during the first four weeks after exposure and then begins to decrease (10), but the bacteria could still be detected for many weeks and in some cases, for several months.

In conclusion, we have successfully used an m-PCR assay to detect $M$. bovis in nasal exudates of naturally infected cattle, as previously reported by others $(13,22,23)$. Indeed, Vitale et al. (1998) reported high specificity and positive predictive value in the detection of MTC in nasal swabs by PCR, and Romero et al. (1999) demonstrated that nasal-mucus samples give better results for the in vivo PCR-based detection of the microorganism than other body fluids such as blood or milk. However, all these previous reports used primers to detect 
MTC species, and identification of $M$. bovis was presumptive. The mPCR used in this study has the advantage that it detects M. bovis specifically, but also simultaneously identifies the presence of $M$. bovis and other non-M. bovis mycobacterial species belonging to MTC. Although limited by the natural evolution of the infection, because shedding of mycobacteria in nasal mucus is required, the m-PCR described here could be used as an effective and highly specific ante mortem ancillary method for surveillance of bovine tuberculosis in herds, if a periodic sampling scheme is followed; or as a confirmatory method for animals with inconclusive intradermal test results, thus assisting the bovine tuberculosis control and eradication program.

\section{ACKNOWLEDGEMENTS}

This study was supported by grants from FAPERJ, FAPEMAT and CNPq.

\section{REFERENCES}

1. Baptista, F.; Moreira, E.C.; Santos, W.L.M.; Naveda, L.A.B. (2004) Prevalência da tuberculose em bovinos abatidos em Minas Gerais. Arq. Bras. Med. Vet.. 56 (5), 577-580.

2. Barry, T.; Glennon, M.; Smith, T.; Gannon, F. (1993). Detection of Mycobacterium bovis in bovine blood by combined PCR and DNA probe methods. Vet Rec. 132 (3), 66-67.

3. Brasil. Ministério da Agricultura, Pecuária e Abastecimento. Regulamento Técnico do Programa Nacional de Controle e Erradicação da Brucelose e Tuberculose, Instrução normativa SDA 6/2004.

4. De Kantor, I.N.; Roswurm, J.D. (1978). Mycobacteria isolated from nasal secretions of tuberculin test reactor cattle. Am. J. Vet. Res. 39 (7), 12331234 .

5. de la Rua-Domenech, R.; Goodchild, A.T.; Vordermeier, H.M.; Hewinson, R.G.; Christiansen, K.H.; Clifton-Hadley, R.S. (2006). Ante mortem diagnosis of tuberculosis in cattle: a review of the tuberculin tests, gamma-interferon assay and other ancillary diagnostic techniques. Res. Vet. Sci. 81 (2), 190-210.

6. Eisenach, K.D.; Cave, M.D.; Bates, J.H.; Crawford, J.T. (1990) Polymerase chain reaction amplification of a repetitive DNA sequence specific for Mycobacterium tuberculosis. J. Infect. Dis. 161, 977-981.

7. Estrada-Chávez, C.; Otero, F.D.; Díaz, C.A.; Villegas-Sepúlveda, N.; González, R.P.; Salazar, D.G. (2004). Concordancia de la PCR y métodos rutinarios para el diagnóstico de tuberculosis bovina. Vet. Mex. 35, 225 236.

8. Figueiredo, E.E.S.; Silvestre, F.G.; Campos, W.N.; Furlanetto, L.V.; Medeiros, L.; Lilenbaum, W.; Fonseca, L.S.; Silva, J.T.; Paschoalin, V.M.F. (2008). Identification of Mycobacterium bovis isolates by multiplex PCR. Braz. J. of Microbiol 39, 1-4.

9. Hermans, P.W.; van Soolingen, D.; Dale, J.W. et al. (1990). Insertion element IS986 from Mycobacterium tuberculosis: a useful tool for diagnosis and epidemiology of tuberculosis. J. Clin. Microbiol. 28, 20512058.

10. Kao, R.R.; Gravenor, M.B.; Charleston, B.; Hope, J.C.; Martin, M.; Howard, C.J. (2007). Mycobacterium bovis shedding patterns from experimentally infected calves and the effect of concurrent infection with bovine viral diarrhoea virus. J. R. Soc. Interface 4, 545-551.

11. McCorry, T.; Whelan, A.O.; Welsh, M.D.; McNair, J.; Walton, E.; Bryson, D.G.; Hewinson, R.G.; Vordermeier, H.M.; Pollock, J.M. (2005). Shedding of Mycobacterium bovis in the nasal mucus of cattle infected experimentally with tuberculosis by the intranasal and intratracheal routes. Vet. Rec. 157, 613-618.

12. McIlroy, S.G.; Neill, S.D.; McCracken, R.M. (1986). Pulmonary lesions and Mycobacterium bovis excretion from the respiratory tract of tuberculin reacting cattle. Vet. Rec. 118, 718-721.

13. Meikle, V.; Scneider, M.; Azenzo, G.; Zumárraga, M.; Magnano, G.; Cataldi, A. (2007). Individual animals of a cattle herd infect with the same Mycobacterium bovis genotype shows important variations in bacteriological, histophathological and immune response parameters. Zoonoses and Public Health 54, 86-93.

14. Neill, S.D.; Hanna, J.; O'Brien, J.J.; McCracken, R.M. (1998). Excretion of Mycobacterium bovis by experimentally infected cattle. Vet. Rec. 123, 340-343.

15. OIE, Terrestrial Manual (2008). Captured january 2009. http://www.oie.int/eng/normes/ mmanual/2008/pdf/2.04.07_bovine_tb.pdf.

16. Poletto, R.; Kreutz, L.C.; Gonzales, J.C.; Barcellos, L.J.G. (2004). Prevalência de tuberculose, brucelose e infecções víricas em bovinos leiteiros do município de Passo Fundo, RS. Ciência Rural 34(2), 595598.

17. Ribeiro, A.R.P.; Lobato, F.C.F.; Abreu, V.L.V.; Faria, E.S.; Silva, J.A. (2003) Pre valência de tuberculose e brucelose bovina no município de Ilhéus. Arq. Bras. Med. Vet. Zootec. 55 (1), 120-122.

18. Rodríguez J.G.; Fissanoti J.C.; Del Portillo P.; Patarroyo M.E.; Romano M.I.; Cataldi A. (1999). Amplification of a 500-basepair fragment from cultured isolates of Mycobacterium bovis. Eur. J. Clin. Microbiol. Infect. Dis. 3: 2330-2332.

19. Romero, R.E.; Garzón, D.L.; Mejía, G.A.; Monroy, W; Patarroyo, M.E.; Murillo, L.A. (1999) Identification of Mycobacterium bovis in bovine clinical samples by PCR species-specific primers. Can. J. Vet. Res. 63, 101-106. 
20. Rothel, J.S; Jones, S.L.; Corner, L.A; Cox, J.C., Wood, P.R. (1992). The gamma-interferon assay for diagnosis of bovine tuberculosis in cattle: conditions affecting the production of gamma-interferon in whole blood culture. Austr. Vet. J. 69 (1).

21. Ruggiero, A.P.; Ikuno, A.A.; Ferreira, V.C.A.; Roxo, E. (2007). Tuberculose bovina: alternativas para o diagnóstico. Arq. Inst. Biol. 74 (1), 55-65.

22. Tejada, A. R.; Diaz, C. A.; Vivero, J. G.; Salazar, J. A. G.; Leon, R. A. T.; Estrada-Chavez, C. (2006) Confirmation of Mycobacterium bovis excretion in nasal exudates by means of nested PCR in a dairy cattle herd. Vet. Mex. 37, 137-146.

23. Vitale F; Capra G; Maxia L; Reale S; Vesco G; Caracappa S. (1998).
Detection of Mycobacterium bovis complex in cattle by PCR using milk, lymph node aspirates and nasal swabs. J Clin Microbiol. 36(4,: 10501055.

24. Yumi U.; Tooru M. (2007). Tuberculosis as a zoonosis from a veterinary perspective. Compar. Immun., Microbiol. \& Infec. Dis. 30, 415-425.

25. Zanini, M.S.; Moreira, E.C.; Lopes, M.T.P.; Salas, C.E. (1998). Detection of Mycobacterium bovis in milk by polymerase chain reaction. J. Ve Med 45,1129-1132.

26. Zumarraga, M.J.; Meickle, V.; Bernardelli, A.; Abdala, A.; Tarabla, H.; Romano, M. I.; Cataldi, A. (2005). Use of touch-down polymerase chain reaction to enhance the sensitivity of Mycobacterium bovis detection. $J$. Vet. Diagn. Invest. 17, 232-238. 